\title{
LYOPHILIZED HIKING FOOD DEVELOPMENT TRENDS
}

\author{
Inese Silicka1, Iveta Dembovska², Erika Teirumnieka ${ }^{3}$ \\ Ivo Dembovskis ${ }^{4}$ \\ ${ }^{1}$ Mg.soc.sc.,lecturer, researcher, Rezekne Academy of Technologies, Rezekne, Latvia, \\ e-mail: inese.silicka.@rta.lv \\ ${ }^{2}$ Mg.oec., lecturer, researcher, Rezekne Academy of Technologies, Rezekne, Latvia, \\ e-mail: Iveta.Dembovska@rta.lv \\ ${ }^{3}$ Mg.chem., lecturer, researcher, Rezekne Academy of Technologies, Rezekne, Latvia, \\ e-mail: erika.teirumnieka@rta.lv \\ ${ }^{4}$ Mg.soc.sc., chairman of the board, Ltd. "Vides projektu studija", Rezekne, Latvia, \\ e-mail: Ivo.Dembovskis@gmail.com
}

\begin{abstract}
Received: 14 October 2020 / Revised: 25 October 2020 / Accepted: 6 November 2020 /
\end{abstract} Published: 30 November 2020

\begin{abstract}
The consumption of functional food is increasing in almost all industrialized countries, not only because of an aging population, but also because of a more enthusiastic lifestyle, which makes meeting the nutritional requirements more difficult. In part, the transition to processed, easily packaged and pre-cooked foods is considered to be a response to long working hours. It resulted in an increased demand for ready-to-eat foods in recent years and it is expected to continue growing. The aim of the research is to study and analyse lyophilized hiking food development trends. Methods used in the research - monographic, synthesis, statistical analysis methods. The research developed proposals for food processing companies for further development of lyophilized food.
\end{abstract}

Keywords: lyophilized hiking food, market development trends.

JEL code: O14, L66.

\section{Introduction}

When it comes to food choice, it is influenced by many factors. Biological factors such as hunger, appetite, and taste. Economic factors such as cost, income, and availability. Physical factors such as access to the product and skills (whether the product has to be prepared in a certain way and how difficult it is to do). Social factors: culture, family, peers, and eating habits. Psychological factors such as mood, stress, guilt, other emotions. In addition, attitudes, beliefs, and knowledge of food complement the desires of customers (The European Food Information Council, 2005). There are indeed many factors that influence a customer's choice. For example, people living in more health-oriented countries, such as the Scandinavian countries, could be more successful potential customers of frozen dried backpacking meals than those with a more sedentary lifestyle and heavier food traditions the global consumer trend survey "Kantar Worldpanel" (which includes 8 countries: the United Kingdom, the United States, Spain, Mexico, Portugal, China, France, and Brazil) developed by the market research group "Kantar" 
found that in 2019 , about a fifth or $19 \%$ of all meals were purchased in readyto-eat format, and in the UK this indicator was as high as $25 \%$. On average, over the last 5 years, since 2014, the share of such meals has increased by 2\%(Kantar, 2019).

The aim of the research is to study and analyse lyophilized hiking food development trends. To achieve the research aim, the authors have set the following specific research tasks: 1) study the factors influencing the choice of food products; 2) study and analyse the demand for hiking food in different countries; 3) analyse lyophilized food manufacturing trends; 4) make conclusions and recommendations.

Research period: 2014-2020.

Hypothesis: Demand for lyophilized hiking food grows each year.

Research novelty: The study and analysis of the demand for hiking food in different countries; lyophilized food manufacturing trends determined.

Research methods: monographic, synthesis, logical construction.

\section{Research results and discussion}

The price continues as the most important factor in determining food choices (Steenhuis et al., 2011). However, for consumers with higher incomes, the consumption patterns may be influenced by factors other than price. The higher the income level, the more consumer behaviour is influenced by factors such as food safety, quality, long shelf life, non-GMOs, and the expected health benefits (Hockmann et al., 2013). There is a growing trend in richer countries, where consumers are more attracted to niche, innovative, and sustainable high-quality products. These consumers are willing to pay extra for such products. Knowing that freeze-drying technology is expensive to operate and maintain, but ultimately delivers high-quality products, focusing on wealthy countries is likely to attract more customers as they are willing to pay more for such products.

In addition to price, consumer preferences are influenced by healthrelated factors (allergies and intolerances, healthy lifestyles, food safety), social responsibility (local products, animal welfare), and convenience (ECSIP consortium, 2016).

Consumer awareness of the link between food and health continues to grow as more information becomes available to the public. Increasing attention to maintaining a healthy lifestyle and active disease prevention is consciously associated with the adoption of a healthy diet (FoodDrinkEurope, 2014; Kasriel-Alexander, 2013). Other indicators that increase consumers' attention to food properties are life-threatening food allergies, food intolerances, and trends such as gluten-free, sugar-free, lactose-free, etc. foods. The latter attracts customers who do not have any 
health problems and follow the main trends instead. It enables healthy and innovative foods to reveal their brands to a larger population. Food safety threats such as e-coli, bovine spongiform encephalopathy (BSE), listeria, and avian influenza have made consumers more concerned about food safety (Newell et al., 2010). At the same time, there is a growing interest in agricultural (use of organic substances, antibiotics, and growth hormones in livestock or pesticides on crops) and processing practices (e.g., the use of certain food additives such as aspartame) (Turi et al., 2014). This growing interest in health and food safety provides a platform for lyophilization to prove itself even more as a safe, efficient, and high-quality food processing method. Many novel foods remain niche products, and consumers tend to reject certain types of novel foods that evoke disgust or lack naturalness. Developers of novel food products must identify consumer expectations and factors leading to consumer rejection at an early stage of product development. (Tuorila et al., 2020) Altering diets is increasingly acknowledged as an important solution to feed the world's growing population within the planetary boundaries. (Parodi et al., 2018)

Consumers are increasingly focusing on purchasing choices and the impact of their chosen products on the climate, public health, social and economic inequalities, animal welfare, etc. Several indicators mentioned by Kristallis et al. (Kristallis et al., 2011) confirm it: (1) increasing sales of organic food in many western countries; (2) efforts to develop alternative distribution channels for locally and regionally produced foods; and (3) major retailers taking steps to become more socially responsible (European Parliament, 2016). This in turn forces manufacturers to work on corporate social responsibility (CSR) strategies. These changes in social responsibility have continued in the creation and operation of the European Food Sustainable Consumption and Production (SCP) Round Table. This initiative is co-chaired by the European Commission and partners in the food supply chain and supported by the United Nations Environment Programme (UNEP) and the European Environment Agency. In this Round Table, various stakeholders are involved in developing and promoting science-based approaches to SCP through interactions all over the food chain. It only confirms that social responsibility is now an integral part of every business and is here to stay.

Convenience is one of the characteristics of a food product that has a growing demand (RECAPT, 2011). Given the current fast-paced lifestyle, there is a greater need for convenient, ready-to-eat meals for hiking food. In addition to the health trends mentioned above, there is a particular demand for healthy food. (Veselības ministrija, 2020) Cooking at home is also affected (Sattethwaite et al., 2010). In urban areas, especially in developed and even developing countries, less and less time is spent cooking and consuming at 
home. As a result, there has been an increasing demand for ready products in recent years, such as frozen or fresh foods, ready-to-eat sauces, sliced vegetables, or fast-food products. This is an opportunity to be seized.

There is a growing demand for high-quality, healthy, socially responsible, safe, and convenient functional foods. Therefore, innovations in lyophilization methodology are welcomed and promising. Despite the already available significant choice of food options, there are customers who are looking for high-quality, innovative, compact, and healthy products and are willing to pay a higher price for them.

Therefore, one of the development options is cooperation with hiking food producers and food processing companies in the following regions:

1. First, in wealthy countries whose populations are active and health conscious. The most common are the Nordic countries (Denmark, Norway, Sweden, Finland, Iceland), as well as Switzerland, Austria, and Germany;

2. Second, countries with a developed active tourism industry that attract active tourists. This is usually the case in mountainous areas, where hiking and active sports (such as skiing) are popular. The US Adventure Travel Trade Association's 2018 industry index (Adventure Travel Trade Association, 2018), created in collaboration with travel agencies, travel agents, adventure tour developers, and other industry players, identifies the most popular hiking destinations by developed and developing countries:

$\begin{array}{cc}\text { Developed countries } & \text { Developing countries } \\ \text { 1. Iceland } & \text { 1. Czech Republic } \\ \text { 2. Switzerland } & \text { 2. Israel } \\ \text { 3. Germany } & \text { 3. Estonia } \\ \text { 4. New Zealand } & \text { 4. Slovakia } \\ \text { 5. Norway } & \text { 5. Poland } \\ \text { 6. Sweden } & \text { 6. Chile } \\ \text { 7. Canada } & \text { 7. Romania } \\ \text { 8. Finland } & \text { 8. Bulgaria } \\ \text { 9. Great Britain } & \text { 9. Slovenia } \\ \text { 10. Australia } & \text { 10. Jordan }\end{array}$

Determining the size of the lyophilized food market is largely limited by the lack of official statistics. In particular, it is related to the existing industry and product classification systems in European countries, such as the Nomenclature of Economic Activities (NACE) and the Combined Nomenclature $(\mathrm{CN})$, as they are mainly based on the traditional characteristics of companies and their products. Since the production of lyophilized food is a relatively new field of activity performed by a small 
number of companies, it is not possible to identify within these systems the involved companies and their sales volumes. Instead, the sales data on lyophilized foods are combined, for example, with data on dehydrated, evaporated, and other similarly processed foods, which together form a group of dried foods.

At the same time, statistics on the dried food group also provide an insight into the general market development trends for lyophilized food, as its demand is made up by the same target groups and their needs. Nevertheless, when evaluating the data, it should be taken into account that lyophilized foods represent a small part of the dried food group, and the distribution of their product categories is slightly different. This is mainly due to the fact that lyophilized foods are more expensive because of higher production costs and, consequently, the producers of these products specialize in categories with higher added value.

Overall, in the period from 2014 to 2019, the import of dried food products to the EU countries has grown steadily both in terms of volume and value, reaching a volume of 16.1 million tons with a value of 33.3 billion euros in 2019. The export in the EU countries have also grown, albeit to a lesser extent, amounting to 11.4 million tons in 2019 with a value of 23.3 million euros (Figure 2). It can also be concluded that in the category of dried foods the EU countries are net importers, as the import to export ratio is about 60 to 40 (expressed in percent) (Eurostat, 2020) .

On the other hand, examining trade data by countries, it can be seen that among the EU countries, Spain, the Netherlands and Germany are the largest exporters of dried food and ready-to-eat meals in terms of volume, accounting for $28 \%, 19 \%$, and $8 \%$ of total EU exports in 2019, respectively. Hence, it can be concluded that the net balance of production in these countries after domestic consumption is the highest, and these countries are the most active in drying of food products and the use of related equipment. Meanwhile, the volume of imports of such products is also the highest in the Netherlands, Germany, and the UK, importing in 2019 16\%, 14\%, and 11\% of the total EU import. This indicates that in these countries either the further use of dried food in the production of combined products and meals or packaging, marketing, and sales activities for already imported dried products, as well as the consumption of these products (e.g., in the hiking tourism sector) are the most common.

In general, in the food group, the lyophilization process is mainly used for processing fruits, as there is a wide market for fruits processed in this way; these dried fruits can be used as a snack themselves and as an ingredient in such products as breakfast cereals, snack bars, desserts, confectionery, etc. Lyophilized fruits and their ingredients are also used in the HoReCa industry. The fruit category is estimated to account for about a 
third of the total lyophilized food market (Market Research, 2017). Lyophilization is used less frequently in the processing of vegetables, mushrooms, meat and fish, as well as dairy products, and mainly to only to use these foods as ingredients in the production of various products and ready-to-eat meals, including hiking and emergency meals. In the production of dried vegetables as a snack, the most common process is vacuum frying. However, new, albeit very small, producers of lyophilized vegetable snacks are emerging, such as the UK-based Bruce Farms Limited lyophilized pea snacks line Podberry (Podberry, 2020). In the category of beverages, the lyophilization process is quite often used in the production of instant tea, coffee, smoothies, fruit and milk drinks.

After selecting the largest lyophilized food producers, reviewing their number and turnover, as well as taking into account the estimations of the information analysis company Mordor Intelligence (Mordor Intelligence, 2019) it can be concluded that the total turnover of 15 well-known specialized producers exceeds 240 million euros (Figure 1), and the dominating countries in this area are Germany, Spain, Great Britain, Norway, Italy, France.

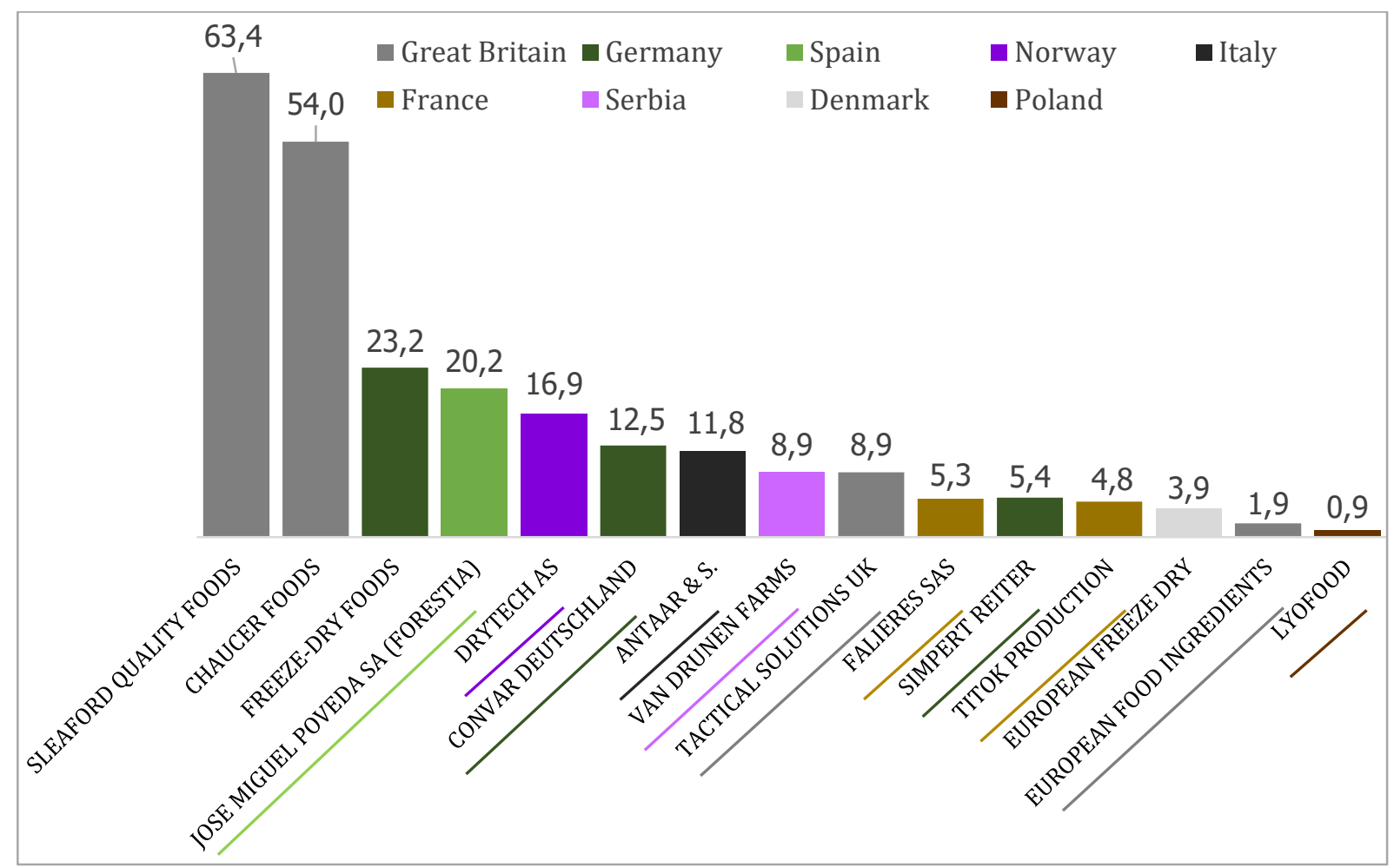

Note: The companies that also produce hiking food are underlined

Fig 1. Largest as well as other specialized lyophilized food producers in European countries and their turnover in the last known year (2013-2019), mln. Euro (Mordor Intelligence, 2019) 
There are also other large players in the industry for which the turnover is not publicly known, such as the German-based Paradise Fruits Solutions $\mathrm{GmbH} \&$ Co. Kg (www.paradise-fruits.de), Poland-based Greenfield Sp. zoo (www.greenfield.eu.com), and other companies.

It should also be borne in mind that lyophilized foods and their ingredients are offered not only by specializing companies but also by international food market giants. For example, lyophilized food ingredients also make part of an offer of the German-based food ingredient manufacturer Doehler Group SE (Doehler Group, 2018), whose turnover in 2018 reached $1,768.4$ million euros, which is about 7 times the total turnover of 15 specialized food producers considered together. Although it is not possible to determine exactly how much of the total turnover of Doehler Group SE can be attributed to the lyophilized food niche, it is known that a large part of Doehler Group SE's activities in this niche is based on the lyophilized food ingredients manufacturer Molda acquired in 2015, whose annual turnover before the acquisition was around 84 million euros (Doehler Group, 2018).

Overall, of the listed specialized lyophilized food producers, most also produce hiking food lines as part of their offer but these are the smallest companies in terms of turnover. The companies specializing exclusively in the production of hiking food are even smaller. This shows that hiking food is a narrow niche with a lower level of market concentration than in the lyophilized food market as a whole, since the production in this niche is relatively small, leading to lower investment and a higher number of market participants. In this niche, similarly to the general lyophilized food market, the main represented countries are the already mentioned UK, Germany, Norway, Spain, Italy, France with the mentioned companies, but there are also some medium-sized players in Poland - Lyo Food Sp. z 0.0 (www.lyofood.com), in the Netherlands - Adventure Food B.V. (www.adventurefood.com), Sweden - Bla Band Kemtvatt (www.blaband.se), Czech Republic - Adventure Menu (www.adventure-menu.com), Estonia Tactical Solution OU (www.tacticalfoodpack.com) and other countries.

Although data on the turnover and other performance indicators of these relatively small companies are limited, the latest information on market developments shows a positive overall trend. For example, in the second half of 2020, Danish-based lyophilized food ingredients manufacturer European Freeze Dry ApS (European Freeze Dry, 2020) announced investments of almost 2 million euros in factories in Denmark and the UK to expand production capacity in response to the rapidly growing demand for their products. The company's representative told the media that the development has accelerated as a result of the pandemic, since there is an increase in demand for products and ingredients with a long shelf life (Food Manufacture, 2020). However, even in the pre-pandemic period, the 
company saw a sharp increase in turnover, which in turn was due to the growing demand for high-protein legumes in particular, which was largely driven by the development of a vegan and vegetarian product niche (New Food Magazine, 2020).

\section{Conclusions and proposals}

That the development of the lyophilized food market is still relatively slow and characterized by high market concentration. The relatively high level of costs and know-how required to start lyophilized food production acts as a significant barrier for new entrants. This is particularly the case in European countries, where there is a small number of companies using lyophilisation technologies and they have a significant market share.

Consumer awareness of the link between food and health continues to grow because more information becomes available to the public. Demand for high quality, healthy, socially responsible, safe, practical and functional food products is growing. This is why novelties in lyophilization methodology are appreciated and promising. Despite the considerable selection of food that already exists, there are still clients looking for high quality, innovative, compact and healthy products who are willing to pay a higher price for them. Based on the market analysis data, the priority countries for hiking destinations among the developed countries are: 1. Iceland, 2. Switzerland, 3. Germany, 4. New Zealand, 5. Norway, 6. Sweden, 7. Canada, 8. Finland, 9. UK, 10. Australia. Potential partners identified in the FS represent countries such as the Netherlands, Norway, the United Kingdom, France, Germany, Poland, Estonia and the Czech Republic. As these lists feature 4 (Switzerland, Germany, UK, France) out of 5 European patent countries (Switzerland, Germany, UK, France, and Ireland), after the PCT patent application, it is envisaged to advance the protection of the technology with the European patent, which will provide protection in Switzerland, Germany, the UK, France, and Ireland. Potential customer/cooperation partner segments were identified:

5) food lyophilization equipment manufacturers;

6) food manufacturers specializing in the production of various types of processed hiking snacks or instant meals that do not offer lyophilized food product lines;

7) food manufacturers specializing in the production of various dried (dehydrated, air-flow, vacuum, etc. dried) or vacuum-dried food products that do not offer lyophilized food product lines;

8) food manufacturers specializing in the production of lyophilized food products and meals that do not offer hiking product lines; 
9) manufacturers of hiking clothing, equipment, and accessories who would be interested in expanding their brand offer with a food line;

10) organic farming and raw materials manufacturers.

\section{References}

1. Adventure Travel Trade Association (2018). Adventure Tourism Development Index. Retrieved from https://cdnresearch.adventuretravel.biz/research/5bbf8fe92ba5b5.97894d412/ATDI-2018Report.pdf

2. Doehler Group (2018). Molda AG becomes Döhler Dahlenburg. Retrieved from https://www.doehler.com/en/news-media/press/details/molda-ag-becomesdoehler-dahlenburg.html

3. ECSIP consortium (2016). Study: The competitive position of the European food and drink industry. Retrieved from https://ec.europa.eu/growth/content/studycompetitive-position-european-food-and-drink-industry-0 en

4. European Freeze Dry (2020). About us. Retrieved from www.europeanfreezedry.com

5. European Parliament (2016). Short Food Supply Chains and local food systems in the $E U . \quad$ Retrieved from https://www.europarl.europa.eu/RegData/etudes/BRIE/2016/586650/EPRS BRIC 2016)586650 EN.pdf

6. Eurostat (2020). EU Trade Since 1988 By CN8. Retrieved from http://epp.eurostat.ec.europa.eu/newxtweb/

7. Food Manufacture (2020). European Freeze Dry invests $1.5 \mathrm{~m}$ in UK and Denmark food factories. Retrieved from https://www.foodmanufacture.co.uk/Article/2020/07/31/European-Freeze-Dryinvests-1.5m-in-UK-and-Denmark-food-factories

8. FoodDrinkEurope (2014). Data \& Trends of the EU Food Industry 2013-2014. Retrieved from https://www.fooddrinkeurope.eu/uploads/publications documents/Data Trends of the European Food and Drink Industry 2013-20141.pdf

9. Hockmann, H., Levkovych, I., Grau, A. (2013). Review of Recent Developments in the Agri-Food Sector: Working Paper. COMPETE Project. Retrieved from www.competeproject.eu.

10. Kantar (2019). Eat, drink and be healthy: How at-home consumption is changing. Retrieved from https://www.kantarworldpanel.com/dwl.php?sn=publications\&id=1304

11. Kasriel-Alexander, D. (2013). Top 10 Global Consumer Trends For 2014. Retrieved from https://blog.euromonitor.com/white paper/the-top-10-global-consumertrends-for-2014/

12. Krystallis, A., Scholderer, J., Brunsø, K., Grunert, K.G., Esbjerg, L., Lahteenmaki, L., Bech-Larsen, T. (2011). Overview of Consumer Trends in the food sector 2010-2015, MAPP Report. Retrieved from https://pure.au.dk/portal/files/70401792/Overview of Consumer Trends in Food Industry.pdf

13. Market Research (2017). Global Freeze Dried Food. Retrieved from https://www.marketresearch.com/Mordor-Intelligence-LLP-v4018/Global-FreezeDried-Food-11241068/ 
14. Mordor Intelligence (2019). Industry reports: Europe Freeze dried Food Market. Retrieved from https://www.mordorintelligence.com/industry-reports/europefreeze-dried-food-market

15. Newell, D.G., Koopmans, M, Verhoef, L, et al. (2010). Food-borne diseases - the challenges of 20 years ago still persist while new ones continue to emerge. International Journal of Food Microbiology, 139 (suppl 1): S3-S15. 10.1016/j.ijfoodmicro.2010.01.021

16. NewFoodMagazine (2020). Food producer reports huge rise in sales of freeze dried ingredients.

Retrieved

from

https://www.newfoodmagazine.com/news/106236/food-producer-reports-hugerise-in-sales-of-freeze-dried-ingredients/

17. Parodi, A., Leip, A., De Boer, I.J.M. et al. (2018). The potential of future foods for sustainable and healthy diets, Nature Sustainability, 1, 782-789. https://doi.org/10.1038/s41893-018-0189-7

18. Podberry (2020). Crunchy pea snacks that popwith flavour. Retrieved from www.eatpodberry.co.uk

19. RECAPT (2011). Retailer and Consumer Acceptance of Promising Novel Technologies and Collaborative Innovation Management [Overview of Consumer Trends in Food Industry]. Retrieved from https://cordis.europa.eu/project/id/289755/reporting/es

20. Satterthwaite, D., McGranahan, G., Tacoli, C. (2010). Urbanization and its implication for food and farming. Philosophycal Transactions of Royal Society B, 365, 2809-2820. doi.org/10.1098/rstb.2010.0136

21. Steenhuis, I., Waterlander, W.E., Mul, A. (2011). Consumer food choices: the role of price and pricing strategies. Public Health Nutrion, 14(12), 2220-2226. https://doi.org/10.1017/S1368980011001637

22. The European Food Information Council (2005). The Determinants of food choice. EUFIC REVIEW 04/2005. Retrieved from http://ernaehrungsdenkwerkstatt.de/fileadmin/user upload/EDWText/T(extElem ente/Ernaehrungswissenschaft/EUFIC-

FoodToday/Determinants fo Food Choice EUFIC Reviews.pdf

23. Turiola, H., Hartmann, Ch. (2020). Consumer responses to novel and unfamiliar foods. Current Opinion in Food Science, 33, 1-8. https://doi.org/10.1016/i.cofs.2019.09.004

24. Turi, A., Goncalves, G., Mocan, M. (2014). Challenges and competitiveness indicators for the sustainable development of the supply chain in food industry. Elsevier. Procedia - Social and Behavioural Sciences, 124, 133 - 141. DOI: $10.1016 / j . s b s p r o .2014 .02 .469$

25. Veselības ministrija (2020). Veselības ministrijas izstrādātie veselīga uztura ieteikumi. Retrieved from http://www.vm.gov.lv/lv/tava veseliba/veseligs dzivesveids/veselibas ministrijas izstradatie veseliga uztura ieteikumi/ 